\title{
PENGARUH PROFITABILITAS, LEVERAGE, FIRM SIZE, DAN EARNINGS POWER TERHADAP MANAJEMEN LABA PADA PERUSAHAAN SEKTOR PROPERTI YANG TERDAFTAR DI BURSA EFEK INDONESIA
}

\author{
Oleh: \\ Yusak Maleakhi Purnama \\ Eindye Taufiq \\ Tri Bhakti Business School
}

\begin{abstract}
ABSTRAK
Tujuan dari penelitian yang dilakukan ini adalah untuk mendapatkan bukti mengenai pengaruh variabel independen yang terdiri dari profitabilitas, leverage, firm size, dan earnings power terhadap variabel dependen manajemen laba. Perusahaan yang digunakan di dalam penelitian ini adalah perusahaan-perusahaan sektor properti yang terdaftar di Bursa Efek Indonesia (BEI) dari tahun 2017-2019 dengan kriteria menggunakan purposive sampling method. Penelitian ini menggunakan perangkat lunak IBM SPSS versi 25. Hasil penelitian menunjukkan bahwa profitabilitas dan earnings power tidak berpengaruh terhadap manajemen laba. Variabel leverage menunjukkan adanya pengaruh positif dan signifikan terhadap manajemen laba. Sedangkan, variabel firm size menunjukkan adanya pengaruh negatif dan signifikan terhadap manajemen laba. Saran penelitian, untuk akademisi dan untuk penelitian selanjutnya, bisa dipertimbangkan untuk mencari faktor-faktor lain yang mungkin memiliki keterkaitan dengan manajemen laba dan melakukan transformasi data agar hasil menjadi lebih baik. Untuk perusahaan agar lebih dapat mengelola tingkat leverage-nya agar dapat terhindar dari praktik manajemen laba. Untuk para investor, agar sebaiknya lebih mempertimbangkan faktor lain selain profitabilitas dan earnings power sebelum menginvestasikan modalnya. Untuk pemerintah, agar lebih waspada bukan hanya pada perusahaan besar, namun juga pada perusahaan kecil untuk mengurangi indikasi praktik manajemen laba. Untuk para pengguna laporan keuangan lainnya, khususnya kreditor, agar lebih berhati-hati dalam menilai sebuah prospek keuangan perusahaan, karena rasio leverage yang rendah, tidak menjamin bahwa perusahaan tidak melakukan praktik manajemen laba.
\end{abstract}

Kata Kunci: Manajemen Laba, Profitabilitas, Leverage, Firm Size, Earning Power

\begin{abstract}
The purpose of this research is to obtain evidence regarding the effect of independent variables consisting of profitability, leverage, firm size, and earnings power towards dependent variable earnings management. The company used in this research is a property company listed on the Indonesia Stock Exchange (IDX) from 2017-2019 with the criteria using purposive sampling method. This research is using IBM SPSS software version $25 . \quad$ The result of this research are variable profitability and earnings power, which partially has no influence on earnings management. However, leverage partially has a positive and significant influence on earnings management. Then, firm size partially has a negative and significant influence on earnings management. Research suggestions, for academics and for further research, it can be considered to look for the other factors that may have a relation with earnings management.
\end{abstract}


For companies to better manage their leverage levels in order to avoid earnings management practices. For investors, to better to consider the other factors besides profitability and earnings power before investing. For the government, to be more alert not only to large companies but also to small companies to reduce indications of earnings management practices. For other users of financial statements, especially creditors, to be more careful in assessing a company's prospects, because the low leverage ratio does not guarantee that the company does not do earnings management practice.

Keywords: Earning Management, Profitability, Leverage, Firm Size, Earning Power

\section{PENDAHULUAN}

\section{Latar Belakang}

Statement of Financial and Accounting Concept (SFAC) No. 2 menyatakan bahwa informasi laba pada umumnya merupakan sesuatu yang menjadi perhatian utama dalam menilai kinerja atau pertanggungjawaban manajemen dan sangat penting pula bagi pihak-pihak yang menggunakannya karena memiliki nilai prediktif (FASB, 1980). Karenanya, banyak perusahaan melakukan upaya untuk melakukan manajemen laba dengan tujuan agar kinerja perusahaan terlihat baik (Pahmi, 2018).

\section{Manajemen laba (earnings} management) adalah suatu kondisi di mana manajemen melakukan campur tangan di dalam proses penyusunan laporan keuangannya yang diperuntukkan bagi pihak eksternal, sehingga dapat meratakan, menaikan atau bahkan menurunkan laba sesuai dengan kebijakan manajemen itu sendiri (Schipper, 1989). PT Hanson Internasional merupakan contoh nyata dari perusahaan besar di Indonesia yang melakukan manipulasi laporan keuangan. Dalam pemeriksaan yang dilakukan oleh 72
OJK, ditemukan manipulasi dalam penyajian akuntansi terkait penjualan Kavling Siap Bangun (Kasiba) yang membuat pendapatan perusahaan pada tahun 2016 naik tajam atau overstated (Idris, 2020).

Beberapa penelitian dilakukan untuk membuktikan pengaruh profitabilitas, leverage, firm size dan earnings power terhadap praktik manajemen laba. Profitabilitas berpengaruh positif terhadap manajemen laba (Irawan, 2013; Selviani, 2017; Fitri dkk, 2018), sedangkan profitabilitas tidak berpengaruh terhadap manajemen laba (Gunawan dkk, 2015; Fatmasari, 2016; Pahmi, 2018; Agustia dan Suryani, 2018). Penelitian mengenai laverage terhadap manajemen laba yang menghasilkan pengaruh positif terhadap manajemen laba (Irawan, 2013; Naftalia dan Marsono, 2013; Savitri, 2014; Fuadillah, 2014; Arifin dan Destriana, 2016; Fatmasari, 2016; Roskha, 2017; Astuti dkk, 2017; Pahmi, 2018; Agustia dan Suryani, 2018), tidak berpengaruh terhadap manajemen laba (Rice, 2013; Elfira, 2014; Simarmata, 2014; Gunawan dkk, 2015; Kurniawati, 2018; Widianingrum dan 
Sunarto, 2018) dan pengaruh negatif terhadap manajemen laba (Kosasih dan Widayati, 2013; Gunarti, 2015; Almadara, 2017; Suyoto dan Dwimulyani, 2019).

Penelitian yang menyebutkan firm size berpengaruh negatif terhadap manajemen laba (Rice, 2013; Simarmata, 2014; Pahmi, 2018) dan firm size tidak berpengaruh terhadap manajemen laba (Sosiawan, 2012; Gunawan dkk, 2015; Astuti dkk, 2017; Kurniawati, 2018). Penelitian yang menjelaskan bahwa earnings power berpengaruh positif terhadap manajemen laba (Sosiawan, 2012; Satryatama, 2015; Surya dkk, 2016; Insani, 2017; Jampar, 2019) dan tidak terdapat pengaruh antara earnings power terhadap manajemen laba (Alhavid, 2015; Taco dan Ilat, 2016). Penelitian lainnya juga menemukan bukti bahwa earnings power berpengaruh negatif terhadap manajemen laba (Munawarah, 2017; Pahmi, 2018). Penelitian ini adalah penelitian replikasi yang merujuk pada penelitian yang dilakukan oleh Ningsaptiti (2010), dengan objek penelitian perusahaan-perusahaan properti yang terdaftar di Bursa Efek Indonesia (BEI) periode 2017 - 2019. Penelitian ini berusaha menyelidiki kembali, apakah terdapat praktik manajemen laba serta menguji kembali faktor-faktor yang mungkin mempengaruhinya seperti profitabilitas, leverage, firm size dan earnings power.

\section{Rumusan Masalah}

Rumusan masalah dari penelitian ini adalah apakah profitabilitas, leverage, firm size, dan earnings power berpengaruh terhadap manajemen laba pada perusahaan sektor properti yang terdaftar di Bursa Efek Indonesia, baik secara parsial maupun simultan.

\section{LANDASAN TEORI}

\section{Teori Keagenan (Agency Theory)}

Teori keagenan adalah sebuah teori yang mendasari praktik bisnis perusahaan, di mana ketika pengelolaan perusahaan tidak lagi dilakukan oleh pemilik (principal), melainkan diserahkan kepada pihak lain/agent (Jensen dan Meckling, 1976). Hubungan agensi ada ketika principal menyewa pihak lain (agent) untuk melaksanakan suatu jasa dan dalam melakukan hal itu, mendelegasikan wewenang untuk membuat keputusan kepada agen tersebut.

\section{Teori Sinyal (Signalling Theory)}

Sinyal atau isyarat adalah sebuah tindakan yang diambil oleh perusahaan untuk memberi sebuah petunjuk bagi para investor mengenai suatu pandangan manajemen terhadap prospek perusahaan (Brigham dan Houston, 2010). Sinyal ini berisikan informasi mengenai apa saja kegiatan yang telah dilakukan oleh manajemen untuk merealisasikan keinginan 
pemilik. Informasi yang dikeluarkan oleh perusahaan, diharapkan bisa dijadikan dasar pengambilan keputusan bagi para investor. Seorang investor yang cerdas, mampu menganalisis informasi lebih lanjut untuk mengetahui apakah suatu informasi yang diberikan oleh perusahaan adalah informasi yang benar atau tidak (Jogiyanto, 2017). Sedangkan, investor yang tidak cerdas akan menerima informasi yang diberikan begitu saja tanpa melakukan analisis lebih lanjut.

\section{Manajemen Laba (Earnings Management)}

Davidson, Stickney dan Weil (1987) mendefinsikan "manajemen laba merupakan proses untuk mengambil langkah tertentu yang disengaja dalam batas-batas prinsip akuntansi berterima umum untuk menghasilkan tingkat yang diinginkan dari laba yang dilaporkan." Setidaknya terdapat dua tujuan yang ingin dicapai oleh seorang manajer dengan melakukan praktik manajemen laba (Sulistyanto, 2008). Pertama, manajer berusaha untuk menyesatkan para pengguna sumber informasi perusahaan untuk membuat keputusan strategis. Kedua, manajer akan memperoleh manfaat pribadi atas kesalahan yang dibuat oleh stakeholder, di mana jika semakin tinggi kesalahan yang dibuat oleh stakeholder dalam mengambil keputusan, maka semakin tinggi pula manfaat pribadi yang nantinya akan diterima oleh manajer.

\section{Profitabilitas}

Rasio profitabilitas mengukur kemampuan perusahaan dalam menghasilkan keuntungan (profitabilitas) pada tingkat penjualan, aset dan modal saham yang tertentu (Hanafi dan Halim, 2016). Profitabilitas mengindikasikan bahwa perusahaan memiliki kehandalan dalam menghasilkan laba dan memanfaatkan aktiva secara produktif selama periode waktu tertentu (Munawir, 2014). Profitabilitas merupakan suatu kemampuan perusahaan menghasilkan laba yang diperoleh dari penjualan, total aktiva dan modal yang dimiliki sendiri (Sartono, 2015). Profitabilitas digunakan investor untuk memprediksi laba dan riko atas investasi yang mereka lakukan. Rasio profitabilitas digunakan untuk memberikan gambaran mengenai keefektifan perusahaan dalam menjelakan kegiatan operasionalnya sehingga memberikan keuntungan bagi perusahaan (Kasmir, 2017).

\section{Leverage}

Menurut Fahmi (2015), rasio leverage adalah sebuah rasio yang mengukur seberapa besar perusahaan dibiayai dengan utang. Penggunaan utang yang terlalu tinggi akan membuat perusahaan berada dalam kategori extreme 
leverage (utang ekstrem) yaitu perusahaan terjebak dalam tingkat utang yang tinggi dan sulit untuk melepaskan beban utang tersebut. Adapun menurut Pertiwi (2019), tingginya rasio leverage membuat perusahaan menjadi tidak solvable, yang artinya total utang yang dimiliki oleh suatu perusahaan lebih besar jika dibandingkan dengan total aset yang dimilikinya.

\section{Firm Size}

Ukuran perusahaan adalah suatu skala di mana dapat mengklasifikasikan besar kecil suatu perusahaan menurut berbagai cara, antara lain total aset, log size, nilai pasar saham, dan lain-lain (Suwito dan Arleen, 2005). Ukuran perusahaan mewakili karakteristik perusahaan yang ditunjukkan dengan jumlah karyawan, besaran penjualan, kapitalisasi pasar dan jumlah asset (Aramburu dan Saenz, 2011). Gibson (1998) menjelaskan bahwa ukuran perusahaan adalah "comparisons firm of different sizes may be more difficult than comparison of firm of equal size. Larger firms often acces to wider and more sophisticated capital markets, can buy this large quantities, and service wider market".

\section{Earnings Power}

Earnings power adalah kemampuan untuk mengetahui efisiensi perusahaan dengan melihat besar kecilnya dalam menghasilkan laba. Para investor tersebut beranggapan bahwa earnings power yang tinggi akan menjamin pengembalian investasi serta akan memberikan keuntungan yang layak, oleh karenanya perusahaan harus menampilkan kinerja manajemen yang baik sehingga earnings power perusahaan dapat dilihat secara maksimal. (Riyanto, 2008).

\section{Penelitian Terdahulu dan Pengembangan}

\section{Hipotesis}

\section{Pengaruh Profitabilitas dengan}

\section{Manajemen Laba}

Pengaruh profitabilitas dengan manajemen laba juga berkaitan dengan bonus plan hypothesis (Wiyadi et al., 2015). Jika dalam tahun berjalan laba perusahaan di bawah persyaratan kinerja aktual untuk bonus, maka manajer pasti terdorong untuk melakukan tindak manajemen laba dengan cara meningkatkan keuntungan. Penelitian yang dilakukan oleh Selviani (2017), Irawan (2013), Fitri dkk (2018), membuktikan bahwa terdapat pengaruh positif antara profitabilitas dengan praktik manajemen laba. Sehingga hipotesisnya adalah:

$\mathrm{H}_{1}$ : Profitabilitas berpengaruh terhadap Manajemen Laba

\section{Pengaruh Leverage dengan Manajemen}

\section{Laba}

Hasty (2017) menjelaskan bahwa dalam pengambilan sebuah keputusan, manajemen dapat menggunakan atau 
mempertimbangkan keputusannya dengan dua cara yaitu tingkat pengembalian (return) dan resiko (risk). Jika tingkat leverage pada perusahaan lebih tinggi, maka manajemen dapat mengindari adanya pelanggaran perjanjian hutang dan kemungkinan adanya praktik manajemen laba tentu akan menjadi sangat besar, sehingga perusahaan mempunyai kewajiban yang lebih besar dalam pengungkapan publik. Penelitian yang dilakukan oleh Naftalia dan Marsono (2013), Irawan (2013), Savitri (2014), Fuadillah (2014), Arifin dan Destriana (2016), Fatmasari (2016), Astuti $d k k$ (2017), Roskha (2017), Agustia dan Suryani (2018), Pahmi (2018), yang memperoleh hasil bahwa leverage berpengaruh positif terhadap praktik manajemen laba. Maka dari itu, hipotesisnya adalah:

$\mathrm{H}_{2}$ : Leverage berpengaruh terhadap Manajemen Laba

\section{Pengaruh Firm Size dengan Manajemen}

\section{Laba}

Ukuran perusahaan (firm size) merupakan suatu skala yang dapat dijadikan sebagai pengklasifikasian dalam besar atau kecilnya suatu perusahaan. Pada dasarnya, ukuran perusahaan dibagi ke dalam tiga kategori, yaitu perusahaan besar (large firm), perusahaan menengah (medium firm) dan perusahaan kecil (small firm), di mana total aset suatu perusahaan dapat dijadikan sebagai dasar untuk menentukan sebuah ukuran perusahaan. Ross

menjelaskan ukuran perusahaan terhadap manajemen laba dapat dijelaskan dengan menggunakan pendekatan signalling theory, dimana besarnya suatu perusahaan akan menjadi sebuah sinyal bagi masyarakat dalam menunjukkan besarnya informasi yang terkandung di dalamnya. Dengan begitu, masyarakat akan memandang perusahaan besar dianggap lebih andal dalam menyajikan laporan keuangannya. Penelitian serupa telah dilakukan terkait pengaruh firm size dengan manajemen laba, seperti penelitian yang dilakukan oleh Rice (2013), Simarmata (2014), Pahmi (2018), dimana hasil penelitian membuktikan bahwa firm size berpengaruh negatif terhadap manajemen laba. Sehingga, hipotesisnya adalah:

$\mathrm{H}_{3}$ : Firm Size berpengaruh terhadap Manajemen Laba

\section{Pengaruh Earnings Power dengan Manajemen Laba}

Umumnya, salah satu aspek yang digunakan oleh para pelaku pasar untuk dijadikan dasar dalam menilai prospek suatu usaha adalah earnings power (Pahmi, 2018). Investor beranggapan bahwa earnings power yang tinggi sudah pasti akan menjamin pengembalian investasi dan memberikan keuntungan yang layak. Earnings power biasanya digunakan oleh para calon investor dalam menilai efisiensi 
suatu usaha dalam halnya menghasilkan laba, sehingga hal itu mendorong motivasi manajemen untuk melakukan praktik manajemen laba.

Penelitian yang dilakukan oleh Satryatama (2015) memperoleh hasil secara keseluruhan dan membuktikan bahwa earnings power suatu perusahaan dapat mendorong motivasi manajer untuk melakukan praktik manajemen laba. Namun, teknik yang digunakan untuk melakukan praktik tersebut bergantung pada motivasi dari pihak manajemen perusahaan itu sendiri. Purnomo \& Pratiwi (2009) berpendapat bahwa kemampuan perusahaan dalam menghasilkan laba dapat mendorong pihak manajemen untuk melakukan modifikasi laba baik dengan cara income increasing accrual atau income decreasing accrual, namun pengaruhnya cenderung lemah. Penelitian lain juga memperoleh hasil di mana earnings power berpengaruh positif terhadap praktik manajemen laba. Seperti penelitian yang dilakukan oleh Sosiawan (2012), Surya $d k k$ (2016), Insani (2017), Jampar (2019), dimana hasil diperoleh dan membenarkan bahwa adanya keterkaitan antara earnings power dan manajemen laba. Sehingga dugaan sementaranya adalah:

$\mathrm{H}_{4}$ : Earnings Power berpengaruh terhadap Manajemen Laba

\section{METODOLOGI PENELITIAN Populasi dan Sampel}

Populasi di dalam penelitian ini adalah perusahaan-perusahaan yang terdaftar di Bursa Efek Indonesia. Sedangkan sampel yang mewakili populasi dalam penelitian ini adalah perusahaan sektor properti yang terdaftar di Bursa Efek Indonesia, dari tahun 2017-2019. Adapun teknik yang digunakan dalam penelitian ini yaitu menggunakan purposive sampling method dengan kriteria: 1. Perusahaan properti yang terdaftar di Bursa Efek Indonesia selama 3 (tiga) tahun berturut-turut, periode 20172019.

2. Perusahaan yang menghasilkan laba positif selama periode penelitian, periode 2017-2019.

3. Menyajikan data yang dibutuhkan dalam penelitian ini secara lengkap selama periode penelitian, yaitu dari tahun 2017-2019.

\section{Variabel Penelitian dan Definisi Operasional Variabel \\ Variabel Dependen \\ Manajemen Laba}

Manajemen laba adalah suatu kondisi di mana manajemen melakukan intervensi dalam proses penyusunan laporan keuangan bagi pihak eksternal sehingga meratakan, menaikkan dan menurunkan pelaporan laba (Insani, 2017). Manajemen laba diukur dengan proksi discretionary 
accruals dan dihitung dengan Jones Model

(1991), dengan tahapan:

a. Menghitung nilai total akrual

$$
\text { TAC }=\text { Net Income }- \text { Cash Flow from Operational }
$$

b. Menghitung estimasi total akrual dengan Ordinary Least Squares (OLS)

$$
\frac{\text { TAit }}{\text { Ait }-1}=\beta 1\left(\frac{1}{\text { Ait }-1}\right)+\beta 2\left(\frac{\Delta \text { Salesit }}{\text { Ait }-1}\right)+\beta 3\left(\frac{\text { PPEit }}{\text { Ait }-1}\right)
$$

c. Menghitung nondiscretionary accruals (NDA)

$$
N D A i t=\beta 1\left(\frac{1}{\text { Ait }-1}\right)+\beta 2\left(\frac{\Delta \text { Salesit }-\Delta \text { Recit }}{\text { Ait }-1}\right)+\beta 3\left(\frac{\text { PPEit }}{\text { Ait }-1}\right)
$$

d. Menghitung discretionary accruals (DA)

$$
\text { DAit }=\frac{\text { TAit }}{\text { Ait }-1}-\text { NDAit }
$$

Keterangan:

TACit $=$ Total Akrual perusahaan i pada tahun $\mathrm{t}$

DAit $=$ Discertionary Accrual perusahaan i pada tahun $\mathrm{t}$

NDAit = Non Discretionary Accrual perusahaan i pada tahun $\mathrm{t}$

NIit $=$ Laba bersih sebelum pajak perusahaan $\mathrm{i}$ pada tahun $\mathrm{t}$

CFOit = Arus kas dari aktivitas operasi perusahaan i pada tahun $\mathrm{t}$

Ait-1 = Total aktiva pada periode $\mathrm{t}-1$

$\Delta$ Salesit $\quad=$ Selisih penjualan perusahaan i pada tahun $\mathrm{t}$

PPEit $\quad=$ Nilai aktiva tetap perusahaan i pada tahun $\mathrm{t}$

$\Delta$ Recit $=$ Selisih piutang dagang perusahaan $\mathrm{i}$ pada tahun $\mathrm{t}$

$\beta 1, \beta 2, \beta 3=$ Koefisien regresi

\section{Variabel Independen}

\section{Profitabilitas}

Profitabilitas

merupakan

kemampuan perusahaan dalam halnya

menghasilkan laba (Selviani, 2017).

Profitabilitas dalam penelitian ini diukur

dengan menggunakan rasio return on asset
(ROA) yang dapat dirumuskan sebagai berikut:

$$
\text { ROA }=\frac{\text { NET INCOME AFTER TAX }}{\text { TOTAL ASSET }}
$$




\section{Leverage}

Leverage merupakan rasio yang digunakan oleh suatu perusahaan untuk mengukur sejauh mana aktiva perusahaan telah dibiayai oleh penggunaan utang. Pada variabel ini, leverage diukur dengan menggunakan rasio yaitu Debt to Asset Ratio.

$$
D A R=\frac{\text { TOT AL LIABILITIES }}{\text { TOTALASSET }}
$$

\section{Firm Size}

Ukuran perusahaan di dalam penelitian ini dapat diukur dengan logaritma natural (Ln) dari total aset yang dimiliki oleh suatu perusahaan. Total aset digunakan karena dianggap relatif stabil jika dibandingkan dengan total penjualan dan total ekuiti (Firnanti, 2017). Pengukuran dapat diukur dengan rumus sebagai berikut:

$$
S I Z E=\operatorname{Ln}(T O T A L A S S E T)
$$

\section{Earnings Power}

Earnings Power dalam penelitian ini dapat dihitung dengan menggunakan rumus Net Profit Margin (NPM), yaitu untuk melihat kemampuan perusahaan dalam menghasilkan laba (Pahmi, 2018). Earnings Power bisa dirumuskan sebagai berikut:

$$
N P M=\frac{N E T \text { INCOME AFTER TAX }}{\text { TOTAL SALES }}
$$

\section{HASIL DAN PEMBAHASAN}

\section{Hasil Pemilihan Sampel}

Tabel 1. Hasil Pemilihan Sampel

\begin{tabular}{llc} 
No & Keterangan & $\begin{array}{c}\text { Jumlah } \\
\text { Perusahaan }\end{array}$ \\
\hline 1 & Perusahaan properti yang konsisten terdaftar di BEI dari tahun & 67 \\
2 & $\begin{array}{l}\text { 2017 sampai dengan 2019 } \\
2\end{array}$ & $\begin{array}{l}\text { Perusahaan properti yang tidak menyajikan laporan keuangan } \\
\text { secara lengkap dari tahun 2017 sampai dengan 2019 }\end{array}$ \\
3 & $\begin{array}{l}\text { Perusahaan properti yang menghasilkan laba negatif selama } \\
\text { periode penelitian }\end{array}$ & $(19)$ \\
& Sampel dan data yang digunakan dalam penelitian & 37 \\
& Tahun Pengamatan & 3 \\
& Total Sampel Penelitian & 111 \\
& Jumlah data yang dikeluarkan dari uji outlier & $(9)$ \\
& Sampel dan data yang digunakan dalam penelitian setelah outlier & 102 \\
\hline
\end{tabular}

Sumber: Data Diolah, 2020 
Tabel 2. Hasil Uji Statistik Deskriptif

\begin{tabular}{llllll} 
& N & Min & Max & Mean & $\begin{array}{l}\text { Std. } \\
\text { Deviation }\end{array}$ \\
\hline $\begin{array}{l}\text { Earnings } \\
\text { Management }\end{array}$ & 102 & $-0,00017160$ & 0,00041225 & 0,00003521 & 0,00009219 \\
$\begin{array}{l}\text { Profitabilitas } \\
\text { Leverage }\end{array}$ & 102 & 0,00030675 & 0,14533711 & 0,04419405 & 0,03525858 \\
Firm Size & 102 & 0,07632361 & 0,81284016 & 0,42870699 & 0,19097782 \\
Earnings & 102 & 0,00646166 & 1,44084620 & 0,22948847 & 0,25677785 \\
Power & & & & & \\
\hline
\end{tabular}

Sumber: Output SPSS v.25, Data Diolah (2020)

Hasil dari uji statistik deskriptif pada

Tabel 2. di atas, menunjukkan bahwa terdapat 102 data yang digunakan di dalam penelitian ini, Hasil penilaian terhadap variabel manajemen laba (Y) yaitu menghasilkan nilai minimum pada manajemen laba adalah sebesar 0,00017160 yang diperoleh dari PT Bekasi Fajar Industrial Estate Tbk. pada tahun 2018 yang didapat dari TAit/Ait-1 dikurangi Nondiscretionary Accruals (0,00516781 (0,00533941)). Sedangkan nilai maksimum pada manajemen laba adalah sebesar 0,00041225 yang diperoleh dari PT Paramita Bangun Sarana Tbk. pada tahun 2019 yang didapat dari TAit/Ait-1 dikurangi Nondiscretionary Accruals (0,04713978 $(0,04672753))$. Nilai rata-rata (mean) manajemen laba adalah sebesar 0,00003521 dan nilai standar deviasinya adalah sebesar 0,00009219. Hal ini menggambarkan sebagai hal yang kurang baik, karena penyimpangan data yang digambarkan dengan standar deviasi lebih besar dari nilai rata-ratanya. Hasil penilaian terhadap variabel profitabilitas $\left(\mathrm{X}_{1}\right)$ yaitu menghasilkan nilai minimum pada return on asset (ROA) adalah sebesar 0,00030675 yang diperoleh dari PT Gading Development Tbk. pada tahun 2017 yang didapat dari Laba Bersih Setelah Pajak dibagi Total Aset (Rp. 430.230.026 / Rp. 1.402.556.223.275). Sedangkan nilai maksimum pada return on asset (ROA) adalah sebesar 0,14533711 yang diperoleh dari PT Metropolitan Kentjana Tbk. pada tahun 2018 yang didapat dari Laba Bersih Setelah Pajak dibagi Total Aset (Rp. 1.018.559.536.819/Rp. 7.008.254.843.361). Nilai rata-rata (mean) profitabilitas adalah sebesar 0,04419405 dan nilai standar deviasinya adalah sebesar 0,03525858 . Hal ini menggambarkan sebagai hal yang baik, karena penyimpangan data yang digambarkan dengan standar deviasi lebih kecil dari nilai rata-ratanya.

Hasil penilaian terhadap variabel leverage $\left(\mathrm{X}_{2}\right)$ yaitu menghasilkan nilai minimum pada debt to asset ratio (DAR) adalah sebesar 0,07632361 yang diperoleh 
dari PT Greenwood Sejahtera Tbk. pada tahun 2019 yang didapat dari Total Utang dibagi Total Aset (Rp. 580.184.785.916 / Rp. 7.601.642.820.703). Sedangkan nilai maksimum pada debt to asset ratio (DAR) adalah sebesar 0,81284016 yang diperoleh dari PT Adhi Karya (Persero) Tbk. pada tahun 2019 yang didapat dari Total Utang dibagi Total Aset (Rp. 29.681.535.534.528 / Rp. 36.515.833.214.549). Nilai rata-rata (mean) leverage adalah sebesar 0,42870699 dan nilai standar deviasinya adalah sebesar 0,19097782. Hal ini menggambarkan sebagai hal yang baik, karena penyimpangan data yang digambarkan dengan standar deviasi lebih kecil dari nilai rata-ratanya.

Hasil penilaian terhadap variabel firm size $\left(\mathrm{X}_{3}\right)$ yaitu menghasilkan nilai minimum pada logaritma natural dari total aset adalah sebesar 26,91671277 yang diperoleh dari PT Pudjiati Prestige Tbk. pada tahun 2018 yang didapat dari Logaritma Natural dari Total Aset (Ln(Rp. 489.530.579.233)). Sedangkan nilai maksimum pada logaritma natural dari total aset adalah sebesar 32,45445562 yang diperoleh dari PT Waskita Karya (Persero) Tbk. pada tahun 2018 yang didapat dari Logaritma Natural dari Total Aset (Ln(Rp. 124.391.581.623.636)). Nilai rata-rata (mean) firm size adalah sebesar 29,74553936 dan nilai standar deviasinya adalah sebesar 1,35800200. Hal ini menggambarkan sebagai hal yang baik, karena penyimpangan data yang digambarkan dengan standar deviasi lebih kecil dari nilai rata-ratanya.

Hasil penilaian terhadap variabel earnings power $\left(\mathrm{X}_{4}\right)$ yaitu menghasilkan nilai minimum pada net profit margin adalah sebesar 0,00646166 yang diperoleh dari PT Gading Development Tbk. pada tahun 2017 yang didapat dari Laba Bersih Setelah Pajak dibagi Total Pendapatan (Rp. 430.230.026 / Rp. 66.581.958.479). Sedangkan nilai maksimum pada net profit margin adalah sebesar 1,44084620 yang diperoleh dari PT Greenwood Sejahtera Tbk. pada tahun 2019 yang didapat dari Laba Bersih Setelah Pajak dibagi Total Pendapatan (Rp. 126.542.082.915 / Rp. 87.824.837.112). Nilai rata-rata (mean) earnings power adalah sebesar 0,22948847 dan nilai standar deviasinya adalah sebesar 0,25677785. Hal ini menggambarkan sebagai hal yang kurang baik, karena penyimpangan data yang digambarkan dengan standar deviasi lebih besar dari nilai rata-ratanya. 


\section{Hasil Uji Asumsi Klasik}

\section{Uji Normalitas}

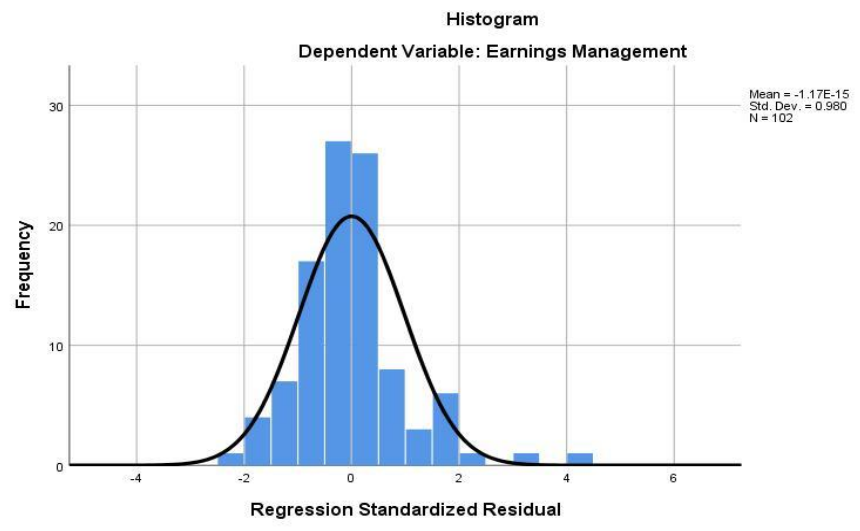

Sumber: Data Diolah (2020)

Gambar 1. Hasil Uji Normalitas (Histogram)

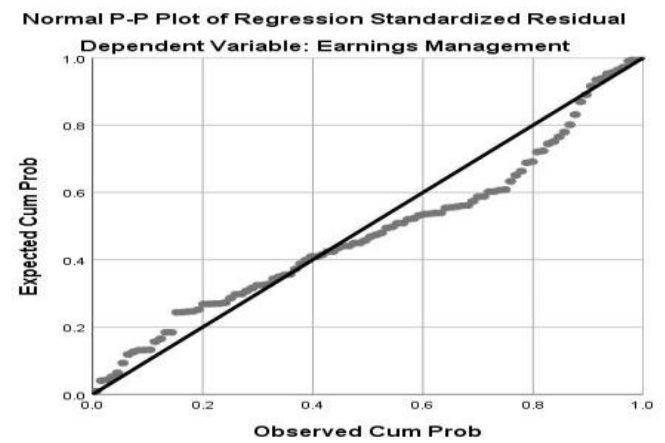

Sumber: Data Diolah (2020)

Gambar 2. Hasil Uji Normalitas (Normal P-P Plot)

Hasil uji normalitas setelah uji garis diagonal dan mengikuti arah garis outlier pada Gambar 1. dan Gambar 2. dapat diagonal, sehingga hal tersebut menjelaskan disimpulkan bahwa grafik Histogram bahwa residual yang dimiliki normal dan cenderung menunjukkan data yang normal dapat dikatakan bahwa asumsi normalitas dan grafik Normal P-P Plot menunjukkan terpenuhi.

bahwa titik-titik terlihat menyebar disekitar 


\section{Uji Multikolinearitas}

Tabel 3. Hasil Uji Multikolinearitas

Sumber: Data Diolah (2020)

\begin{tabular}{llcc} 
Model & & Tolerance & VIF \\
\hline 1 & Profitabilitas & 0,760 & 1,316 \\
& Leverage & 0,418 & 2,391 \\
& Firm Size & 0,596 & 1,678 \\
& Earnings Power & 0,476 & 2,101 \\
\hline
\end{tabular}

Berdasarkan Tabel 3. di atas, dapat disimpulkan bahwa model regresi di dalam penelitian ini telah memenuhi uji VIF-nya di bawah angka 10.

\section{Uji Heteroskedastisitas}

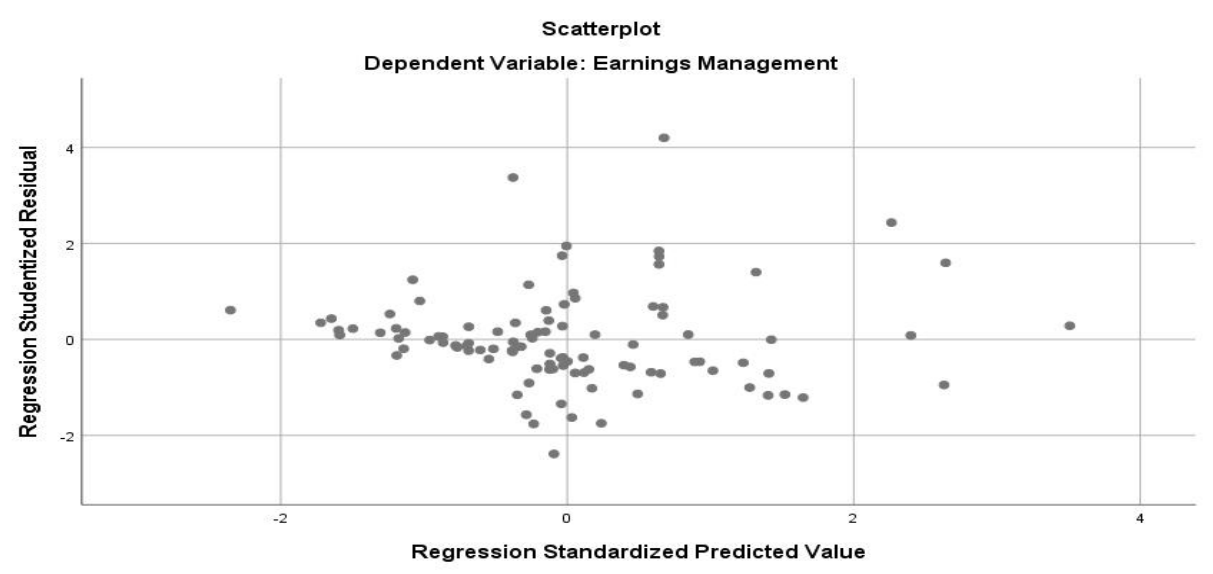

Sumber: Data Diolah (2020)

Gambar 3. Hasil Uji Heteroskedastisitas (Scatterplot)

Melalui Gambar 3. di atas, dapat pada grafik scatterplot di atas, menyebar di disimpulkan bahwa di dalam model atas angka nol dan di bawah angka 0 pada penelitian ini tidak terjadi sumbu $\mathrm{Y}$, yang menunjukkan tidak heteroskedastisitas. Hal ini karena titik-titik terjadinya heteroskedastisitas.

\section{Uji Autokorelasi}

Tabel 4. Hasil Uji Autokorelasi dengan Durbin-Watson

\begin{tabular}{cc}
\hline Model & Durbin-Watson \\
\hline 1 & 1,689 \\
\hline & Sumber: Data Diolah $(2020)$
\end{tabular}

Dari Tabel 4. yang disajikan di atas, di dapat nilai Durbin-Watson sebesar 1,689. Sedangkan nilai dL tabel dan dU tabel masing-masing adalah sebesar 1,5969 dan 1,7596. Keputusan 
dasar untuk menentukan apakah di dalam model penelitian ini tidak terjadi autokorelasi positif adalah jika nilai $\mathrm{D}-\mathrm{W}$ berada di $0<\mathrm{d}<\mathrm{dL}$. Namun, di dalam penelitian ini, nilai D-W berada di $0<\mathrm{d}>\mathrm{dL}$ atau $0<1,689>1,5969$, sehingga tidak dapat diputuskan, apakah di dalam model penelitian ini terdapat autokorelasi atau tidak. Maka itum keputusan yang dapat diambil adalah ragu-ragu.

\section{Hasil Analisis Regresi Berganda}

Tabel 5. Hasil Analisis Regresi

\begin{tabular}{clcccc}
\hline \multirow{2}{*}{ Model } & & \multicolumn{2}{c}{ Unstandardized Coefficients } & t & \multirow{2}{*}{ Sig. } \\
\cline { 3 - 4 } & & $\mathrm{B}$ & Std. Error & & \\
\hline $\mathbf{1}$ & (Constant) & 0,001 & 0,000 & 3,664 & 0,000 \\
\hline & Profitabilitas & 0,000 & 0,000 & 0,871 & 0,386 \\
\hline \multirow{2}{*}{ Leverage } & 0,000 & 0,000 & 3,177 & 0,002 \\
\hline & Firm Size & $-2,972 \mathrm{E}-5$ & 0,000 & $-3,640$ & 0,000 \\
\hline & Earnings Power & $1,444 \mathrm{E}-5$ & 0,000 & 0,299 & 0,766
\end{tabular}

Sumber: Data Diolah (2020)

Dari Tabel 5. di atas, maka dapat dibuat persamaan regresinya sebagai berikut:

$$
\begin{aligned}
& \mathrm{EM}=\alpha+\beta 1 \mathrm{X} 1+\beta 2 \mathrm{X} 2+\beta 3 \mathrm{X} 3+\beta 4 \mathrm{X} 4+\mathrm{e} \\
& \mathrm{EM}=\alpha+\beta 1 \mathrm{PROF}+\beta 2 L E V+\beta 3 S I Z E+\beta 4 E P+\mathrm{e} \\
& \mathrm{EM}=0,001+0,000 \mathrm{PROF}+0,000 L E V-2,972 \mathrm{E}- \\
& 5 S I Z E+1,444 \mathrm{E}-5 E P+0,000
\end{aligned}
$$

Dari hasil di atas, dapat diketahui bahwa variabel firm size (SIZE) memiliki pengaruh ke arah negatif terhadap manajemen laba (EM), sedangkan variabel profitabilitas (PROF), variabel leverage (LEV) dan variabel earnings power (EP) memiliki pengaruh ke arah positif terhadap manajemen laba (EM).

\section{Uji Hipotesis}

\section{Uji Koefisien Determinasi (Adjusted $\boldsymbol{R}^{2}$ )}

Tabel 6. Hasil Analisis Koefisien Determinasi

\begin{tabular}{cccc}
\hline Model & R & R Square & Adjusted R Square \\
\hline 1 & 0,405 & 0,164 & 0,129 \\
\hline
\end{tabular}

Sumber: Data Diolah (2020)

Berdasarkan Tabel 6. di atas, dapat dilihat bahwa nilai Adjusted $R$ Square variabel independen dalam penelitian ini adalah sebesar 0,129 , yang artinya variabel manajemen laba dapat dijelaskan oleh variabel profitabilitas, leverage, firm size, dan earnings power sebesar $12,9 \%$, sedangkan sisanya sebesar $87,1 \%$ dijelaskan oleh variabel independen lainnya. 


\section{Uji F}

Tabel 7. Hasil Uji F

\begin{tabular}{lllllll}
\hline Model & & $\begin{array}{l}\text { Sum of } \\
\text { Squares }\end{array}$ & df & $\begin{array}{l}\text { Mean } \\
\text { Square }\end{array}$ & F & Sig. \\
\hline $\mathbf{1}$ & Regression & 0,000 & 4 & 0,000 & 4,750 & 0,002 \\
\hline & Residual & 0,000 & 97 & 0,000 & & \\
\hline & Total & 0,000 & 101 & & & \\
\hline
\end{tabular}

Sumber: Data Diolah (2020)

Dari Tabel 7. di atas, diperoleh nilai Fhitung sebesar 4,750 dengan nilai signifikansi sebesar $0,002 . \quad F_{\text {tabel }}$ dalam penelitian ini diperoleh dengan menggunakan $\alpha=0,05$, df regression $=4$ dan $\mathrm{df}$ residual $=97$, sehingga $\mathrm{F}_{\text {tabel }}$ diperoleh sebesar 2,47. Maka, hasil $F_{\text {hitung }}$ $4,750>2,47 \mathrm{~F}_{\text {tabel }}$ dengan nilai signifikansi $0,002<0,05$, sehingga $\mathrm{H} 0$ ditolak $\mathrm{Ha}$ diterima. Hal ini menunjukkan bahwa variabel profitabilitas (PROF), leverage (LEV), firm size (SIZE) dan earnings power $(E P)$ secara bersama-sama (simultan) mempunyai pengaruh yang signifikan terhadap manajemen laba (EM) yang diproksikan dengan discretionary accruals. Sehingga, dapat disimpulkan bahwa pengujian terhadap model penelitian ini dikatakan layak (fit).

\section{Uji t}

Tabel 8 Hasil Uji t

$\begin{array}{lll}\text { Model } & \text { t } & \text { Sig. }\end{array}$

\begin{tabular}{llll}
\hline $1 \quad$ (Constant) & 3,664 & 0,000 \\
\hline & Profitabilitas & 0,871 & 0,386 \\
\hline Leverage & 3,177 & 0,002 \\
\hline Firm Size & $-3,640$ & 0,000 \\
\hline Earnings Power & 0,299 & 0,766 \\
\hline
\end{tabular}

Sumber: Data Diolah (2020)

Pada Tabel 8. di atas, telah diketahui atas setiap nilai $t_{\text {hitung }}$ dari setiap variabel independen. Sedangkan, $t_{\text {tabel }}$ yang digunakan yaitu $\mathrm{df}=97$, sehingga $t_{\text {tabel }}$ diperoleh sebesar 1,98472. Hasil thitung variabel profitabilitas sebesar $0,871<$ 1,98472 dari $t_{\text {tabel }}$ dengan tingkat signifikan sebesar 0,386 > 0,05. Maka hipotesis $\mathrm{H}_{1}$ ditolak dan dapat disimpulkan bahwa variabel profitabilitas tidak berpengaruh terhadap manajemen laba. Hasil thitung variabel leverage sebesar 3,177> 1,98472 dari $t_{\text {tabel }}$ dengan tingkat signifikan sebesar $0,002<0,05$. Maka hipotesis $\mathrm{H}_{2}$ diterima 
dan dapat disimpulkan bahwa variabel leverage berpengaruh positif dan signifikan terhadap manajemen laba. Hasil thitung variabel firm size sebesar -3,640>1,98472 dari tabel dengan tingkat signifikan $0,000<$ 0,05. Maka hipotesis $\mathrm{H}_{3}$ diterima dan dapat disimpulkan bahwa variabel firm size berpengaruh negatif dan signifikan terhadap manajemen laba. Hasil thitung variabel earnings power sebesar 0,299 < 1,98472 dari $t_{\text {tabel }}$ dengan tingkat signifikan 0,766> 0,05. Maka hipotesis $\mathrm{H}_{4}$ ditolak dan dapat disimpulkan bahwa variabel earnings power tidak berpengaruh terhadap manajemen laba.

\section{PEMBAHASAN}

\section{Pengaruh Profitabilitas terhadap} Manajemen Laba

Hasil pengujian terhadap hipotesis yang pertama $\left(\mathrm{H}_{1}\right)$, diperoleh hasil bahwa profitabilitas tidak berpengaruh terhadap praktik manajemen laba, sehingga dapat dikatakan bahwa nilai suatu profitabilitas suatu perusahaan tidak mempengaruhi perusahaan untuk melakukan praktik manajemen laba. Hal ini berarti, tinggi ataupun rendahnya tingkat profitabilitas suatu perusahaan, tidak akan mempengaruhi manajemen untuk melakukan praktik manajemen laba. Pihak manajemen biasanya beranggapan bahwa beberapa investor tidak begitu memperhatikan atau mengabaikan informasi return on asset
(ROA) yang ada, sehingga hal itu akan membuat manajemen pun merasa tidak termotivasi untuk melakukan manajemen laba (Agustia dan Suryani, 2018).

Pada stakeholder theory, dijelaskan bahwa stakeholder merupakan pihak yang memiliki kepentingan. Karena itulah, perusahaan sadar bahwa para stakeholder adalah tanggung jawab mereka untuk mensejahterakan para stakeholder-nya. Jadi, semakin tinggi ataupun rendahnya tingkat profitabilitas, tidak akan mempengaruhi sebuah perusahaan untuk melakukan manajemen laba. Hal ini mempertegas bahwa, variabel profitabilitas belum bisa dijadikan sebagai dasar untuk pengambilan keputusan investasi bagi para investor. Penelitian ini mendukung penelitian yang telah dilakukan oleh Gunawan, dkk (2015), Fatmasari (2016), Agustia \& Suryani (2018), dan Pahmi (2018), yang juga memperoleh bukti bahwa tinggi atau rendahnya tingkat profitabilitas suatu perusahaan, tidak akan memotivasi manajemen untuk melakukan praktik manajemen laba.

\section{Pengaruh Leverage dengan Manajemen}

\section{Laba}

Hasil pengujian terhadap hipotesis yang kedua $\left(\mathrm{H}_{2}\right)$, diperoleh bahwa variabel leverage berpengaruh positif dan signifikan terhadap praktik manajemen laba. Hal ini artinya, semakin tinggi rasio leverage suatu 
perusahaan, akan mendorong motivasi seorang manajer perusahaan untuk melakukan praktik manajemen laba.

Pahmi (2018) berpendapat bahwa hal ini sejalan dengan teori sinyal, dimana dijelaskan bahwa perusahaan perlu menyampaikan informasi kepada pihak eksternal, seperti kreditor, supaya pihak tersebut dapat menilai keadaan di masa kini dan bagaimana prospek perusahaan di masa yang akan mendatang, salah satunya dengan melihat kemampuan perusahaan dalam memenuhi kewajibannya. Penelitian ini mendukung penelitian yang dilakukan oleh Irawan (2013), Naftalia \& Marsono (2013), Savitri (2014), Fuadillah (2014), Fatmasari (2016), Arifin \& Destriana (2016), Roskha (2017), Astuti dkk (2017), Agustia \& Suryani (2018), Pahmi (2018).

\section{Pengaruh Firm Size dengan Manajemen}

\section{Laba}

Hasil pengujian terhadap hipotesis yang ketiga $\left(\mathrm{H}_{3}\right)$, diperoleh hasil bahwa variabel firm size berpengaruh negatif dan signifikan terhadap praktik manajemen laba. Hal ini menunjukkan bahwa semakin besar ukuran suatu perusahaan yang dilihat dari total asetnya, maka perusahaan tidak akan termotivasi untuk melakukan praktik manajemen laba. Perusahaan yang semakin besar, maka dipastikan akan lebih dikritisi oleh para pemegang saham, maupun publik, sehingga membuat manajemen untuk lebih berhati-hati dalam mempublikasikan suatu informasi. Pahmi (2018) berpendapat bahwa hal ini sejalan dengan teori sinyal di mana perhatian yang tinggi dari pihak eksternal hanya terdapat pada perusahaan yang besar. Semakin besar ukuran perusahaan, maka akan mendorong perusahaan besar untuk lebih berhati-hati dalam menyajikan laporan keuangannya sehingga hal ini sudah pasti akan membuat perusahaan untuk menghindari praktik manajemen laba. Penelitian ini sejalan dengan penelitian yang dilakukan oleh Rice (2013), Simarmata (2014), Pahmi (2018), yang memperoleh bukti bahwa firm size berpengaruh negatif terhadap manajemen laba.

\section{Pengaruh Earnings Power dengan Manajemen Laba}

Hasil pengujian terhadap hipotesis yang keempat $\left(\mathrm{H}_{4}\right)$, diperoleh hasil bahwa variabel earnings power tidak berpengaruh terhadap praktik manajemen laba. Hal ini artinya, besar kecilnya laba suatu perusahaan, tidak akan mempengaruhi perusahaan untuk melakukan tindakan manajemen laba. Tingkat penjualan yang tinggi pada suatu perusahaan, belum tentu akan menghasilkan laba yang tinggi pula. Hal ini sejalan dengan ungkapan Jogiyanto (2017) dalam Pahmi (2018) di mana dalam teori sinyal, seorang investor yang cerdas, mampu menganalisis sebuah informasi lebih lanjut dalam menentukan apakah informasi 
yang diterima adalah sebuah sinyal yang benar dan tiada cela atau tidak. Sedangkan, investor yang tidak cerdas, sudah pasti akan menerima informasi tanpa melakukan analisis terhadap sinyal/tanda yang diberikan oleh perusahaan lebih lanjut. Hal inilah yang pada akhirnya membuat beberapa calon investor mengabaikan informasi net profit margin suatu perusahaan dalam menilai prospek usaha. Hal ini pun membuat manajemen menjadi tidak termotivasi untuk melakukan manajemen laba. Hal ini juga didasari oleh pemahaman terhadap stakeholder theory, di mana perusahaan harus menjamin kesejahteraan para stakeholder-nya. Penelitian ini sejalan dengan penelitian yang dilakukan oleh Alhavid (2015), Taco \& Ilat (2016), yang memperoleh bukti bahwa tidak adanya pengaruh yang terjadi antara earnings power dengan manajemen laba.

\section{KESIMPULAN DAN SARAN}

Berdasarkan hasil analisis dan pembahasan yang telah dilakukan, maka dapat disimpulkan bahwa variabel profitabilitas dan earnings power diperoleh hasil bahwa variabel keduanya tidak memiliki pengaruh terhadap praktik manajemen laba di sebuah perusahaan. Sedangkan, variabel leverage memperoleh hasil bahwa variabel tersebut berpengaruh positif dan signifikan terhadap manajemen laba. Kemudian, variabel firm size juga terbukti berpengaruh negatif dan signifikan terhadap manajemen laba.

Adapun beberapa rekomendasi dan saran yang dapat peneliti berikan setelah melakukan penelitian ini. Bagi akademisi dan penelitian selanjutnya, agar dapat dikembangkan lagi penelitian ini, seperti menambah faktor independen lain yang mungkin saja mempengaruhi manajemen laba. Bagi perusahaan, agar dapat menghindari rasio leverage yang tinggi, sehingga perusahaan tidak perlu melakukan manajemen laba yang mana jika dilakukan, maka perusahaan akan kehilangan citra baiknya. Untuk investor, agar dapat mempertimbangakn faktor lain selain profitabilitas dan earnings power sebelum membuat keputusan investasi. Hal ini karena profitabilitas dan earnings power belum bisa dijadikan alat untuk mendeteksi adanya manajemen laba atau tidak di sebuah perusahaan. Untuk pemerintah, agar lebih waspada terhadap perusahaan dengan skala kecil yang mungkin saja terindikasi melakukan praktik manajemen laba. Namun diharapkan pula, agar tidak lengah terhadap perusahaan besar. Bagi pengguna laporan keuangan lainnya, khususnya para kreditor, agar lebih berhati-hati dalam menilai sebuah prospek keuangan perusahaan. Rasio leverage yang rendah, tidak menjamin bahwa perusahaan tidak melakukan praktik manajemen laba 


\section{DAFTAR PUSTAKA}

Agustia, Y., Prima \& Suryani, Elly. (2018). Pengaruh Ukuran Perusahaan, Umur Perusahaan, Leverage, dan Profitabilitas Terhadap Manajemen Laba (Studi pada Perusahaan Pertambangan yang Terdaftar di Bursa Efek Indonesia Periode 20142016). Jurnal ASET (Akuntansi Riset). Vol.10 No.1

Alhavid. (2015). Pengaruh Earning Power dan Good Corporate Governance Terhadap Manajemen Laba (Studi Empiris pada Perusahaan Go Public yang Berpartisipasi Dalam CGPI

Tahun 2009-2012). Skripsi Program Studi Akuntansi Fakultas Ekonomi Universitas Negeri Padang

Almadara, H., Ulfa. (2017). Pengaruh Leverage Terhadap Manajemen Laba Dengan Corporate Governance Sebagai Variabel Moderasi pada Perusahaan Perbankan yang Terdaftar di BEI. Skripsi Program Studi Akuntansi Fakultas Ekonomi Universitas Negeri Yogyakarta

Aramburu, Nekane., Saenz, Josune. (2011).

Structural Capital, Innovation Capability and Size Effect : An Empirical Study. Journal of Management and Organization Vol 17 pp 307-325
Arifin, L., \& Destriana, N. (2016). Pengaruh Firm Size, Corporate Governance, dan Karakteristik Perusahaan Terhadap Manajemen Laba. Jurnal Bisnis dan Akuntansi Vol.18 No.1, hlm. 84-93

Astuti, A., Y., Nuraina, E., Wijaya, A. L. (2017). Pengaruh Ukuran Perusahaan dan Leverage Terhadap Manajemen Laba. The 9th FIPA: Forum Ilmiah Pendidikan Akuntansi - Universitas PGRI Madiun. Vol.5 No.1, hlm. 501-514

Brigham, Eugene F. Dan J.F. Houston. (2010). Dasar-Dasar Manajemen Keuangan. Edisi 11. Salemba Empat : Jakarta

Davidson, S., Stickney, C. and Weil, R. (1987). Accounting : The Language of Business. Thomas Horton and Daugter. Sun Lakes Arizona

Elfira, Anisa. (2014). Pengaruh Kompensasi Bonus dan Leverage Terhadap Manajemen Laba (Studi Empiris pada Perusahaan Manufaktur yang Terdaftar di Bursa Efek Indonesia Tahun 2009-2012). Jurnal Akuntansi Vol 2, No 2 (2014)

Fahmi, Irham. (2015). Analisis Laporan Keuangan. Penerbit Alfabeta : Bandung

Fatmasari, Sofia. (2016). Pengaruh Profitabilitas, dan Leverage Terhadap Manajemen Laba pada 
Perusahaan Manufaktur Terdaftar

di Bursa Efek Indonesia Tahun 2012-2014. Skripsi Program Studi Akuntansi Sekolah Tinggi Ilmu Ekonomi Perbanas

Financial Accounting Standards Board. (1980). Statement of Financial Accounting Concepts No.2: Qualitative Characteristics of Accounting Information. Stamford. Connecticut.

Firnanti, Friska. (2017). Pengaruh Corporate Governance, dan Faktor - Faktor lainnya terhadap Manajemen Laba. Jurnal Bisnis dan Akuntansi. ISSN : 1410-9875. Volume 19. Nomor 1, juni 2017: 66-80.

Fitri, Anisa., Muda, Iskandar., Badaruddin. (2018). The Influence of Good Corporate Governance, Leverage, and Profitability on Earning Management with Firm Size as Moderating Variable in The Banking Companies Listed in Indonesia Stock Exchange in The Period of 2012-2016. International Journal of Research \& Review. Vol.5 Issue 9

Fuadillah, Dzulkifli. (2014). Pengaruh Leverage, Ukuran Perusahaan, dan Kualitas Audit Terhadap Manajemen Laba (Studi Empiris pada Perusahaan Manufaktur yang Terdaftar di BEI Periode 2008-
2013). Jurnal Akunesa Vol 4, No 3 (2016)

Ghozali, Imam. (2018). Aplikasi Analisis Multivariate Dengan Program IBM SPSS 25, Edisi 9. Badan Penerbit Undip : Semarang

Gibson, Charles. (1998). Financial Reporting and Analysis. 13 th edition. South-Western Cengage Learning.

Gunarti, Yuliana. (2015). Pengaruh Struktur Kepemilikan, Return on Asset dan Leverage Terhadap Manajemen Laba. Jurnal Akuntansi dan Sistem Teknologi Informasi. Vol.11 No.1, hlm. 9-16

Gunawan, I Ketut., Darmawan, Nyoman., A., Surya., Purnawati, I Gusti., A. (2015). Pengaruh Ukuran Perusahaan, Profitabilitas, dan Leverage Terhadap Manajemen Laba pada Perusahaan Manufaktur yang Terdaftra di Bursa Efek Indonesia (BEI). Jurnal Ilmiah Mahasiswa Akutansi Undiksha Vol.03 No.1

Hanafi, Mamduh M dan Abdul Halim. 2016. Analisis Laporan Keuangan. Edisi Kelima. UPP STIM YKPN : Yogyakarta

Idris, Muhammad. (2020). Jejak Hitam PT Hanson International, Manipulasi Laporan Keuangan 2016., dari https://money.kompas.com/read/202 
0/01/15/160600526/jejak-hitam-pt-

hanson-international-manipulasi-

laporan-keuangan-2016? page $=$ all

Diakses 2 April 2020 pukul 13.00 WIB

Insani, Khairatul. (2017). Pengaruh Earnings Power dan Ukuran Perusahaan Terhadap Manajemen Laba (Studi Empiris pada Perusahaan Manufaktur yang Terdaftar di BEI tahun 2011-2015). Artikel. Jurnal Akuntansi Vol 5, No 1 (2017)

Irawan, W., Arwindo. (2013). Analisis Pengaruh Kepemilikan Institusional, Leverage, Ukuran Perusahaan dan Profitabilitas Terhadap Manajemen Laba (Studi pada Perusahaan Manufaktur yang Terdaftar di Bursa Efek Indonesia (BEI) Periode 20092011). Skripsi. Program Studi Akuntansi Fakultas Ekonomika dan Bisnis Universitas Diponegoro Jampar, F., Jemi. (2019). Pengaruh Earning Power Terhadap Manajemen Laba Dengan Kompensasi Bonus Sebagai Variabel Moderating (Studi Pada Perusahaan Manufaktur yang Terdaftar di Bursa Efek Indonesia Periode 2014-2017). Skripsi Program Studi Akuntansi Fakultas Ekonomi Universitas Sarjanawiyata Tamansiswa
Jensen, Michael C. dan W.H. Meckling. (1976). Theory of The Firm: Managerial Behavior, Agency Cost and Ownership Structure. Journal of Financial Economics 3. Hal 305360.

Jogiyanto, H.M. (2017). Teori Portfolio dan Analisis Investasi, Edisi 11. BPFE : Yogyakarta

Jones, Jennifer J. (1991). Earnings Management During Import Relief Investigations. Journal of Accounting Research, Vol 29, No.2 1991, p.193- 228.

Kasmir. (2017). Analisis Laporan Keuangan. PT Rajagrafindo Persada : Jakarta

Kosasih, F., N., \& Widayati, C. (2013). Pengaruh Independensi Komite Audit, Efektivitas Komite Audit dan Leverage Terhadap Praktik Manajemen Laba Pada Perusahaan di Sektor Industri Manufaktur yang Terdaftar di BEI Periode 2009-2011. Jurnal Akuntansi. Vol.XVII No.1, hlm. 132-148

Kurniawati, D., Ayu. (2018). Analisis Pengaruh Leverage, Ukuran Perusahaan, Komite Audit, dan Profitabilitas Terhadap Manajemen Laba (Studi Empiris Perusahaan Manufaktur yang Terdaftar di BEI Periode 2014-2016). Skripsi Program Studi Akuntansi Fakultas 
Ekonomi dan Bisnis Universitas Muhammadiyah Surakarta

Munawarah. (2017). Pengaruh Earning Power, Firm Size, dan Leverage Terhadap Earning Management Pada Perusahaan Sub Sektor Food and Beverage yang Terdaftar di Bursa Efek Tahun 2011-2015. Jurnal Mutiara Akuntansi. Vol.2 No.1, hlm. 89-98

Munawir. 2014. Analisis Laporan Keuangan. Liberty: Yogyakarta

Naftalia, V., Chivan \& Marsono. (2013). Pengaruh Leverage Terhadap Manajemen Laba dengan Corporate Governance Sebagai Variabel Pemoderasi. Diponegoro Journal of Accounting. Vol.2 No.3, hlm. 1-8

Ningsaptiti, Restie. (2010). Analisis Pengaruh Ukuran Perusahaan dan Mekanisme Corporate Governance Terhadap Manajemen Laba (Studi Empiris pada Perusahaan Manufaktur yang Terdaftar di Bursa Efek Indonesia 2006-2008). Skripsi. Program Studi Fakultas Ekonomi Universitas Diponegoro

Pahmi, A., Rezki. (2018). Pengaruh Profitabilitas, Leverage, Struktur Modal, Ukuran Perusahaan, dan Earnings Power Terhadap Manajemen Laba (Studi Empiris pada Perusahaan yang Terdaftar pada Indeks LQ-45 di Bursa Efek
Indonesia Tahun 2013-2017).

Skripsi Program Studi Fakultas

Ekonomi Universitas Islam

Indonesia

Pertiwi, E., Hana. (2019). Pengaruh

Ukuran Perusahaan, Leverage,

Profitabilitas Terhadap Harga

Saham yang Terdaftar di Bursa Efek

Indonesia. Skripsi Program Studi

Akuntansi Tri Bhakti Business

School

Purnomo, B., S., \& Pratiwi, P. (2009). Pengaruh Earning Power Terhadap Praktek Manajemen Laba (Earning Management) (Suatu Kasus Pada Perusahaan Go Public Sektor Manufaktur). Jurnal Media Ekonomi. Vol.14 No.1

Rice. (2013). Pengaruh Leverage, Kepemilikan Institusional, Ukuran Perusahaan dan Nilai Perusahaan Terhadap Tindakan Manajemen Laba. Jurnal Wira Ekonomi Mikroskil. Vol.3 No.1

Riyanto, Bambang. 2008. Dasar-Dasar Pembelajaran Perusahaan. Edisi 4. LPBFE : Yogyakarta

Roskha, Zulfikri. (2017). Pengaruh Leverage, Good Corporate Governance, dan Ukuran Perusahaan Terhadap Manajemen Laba (Studi pada Perusahaan Manufaktur yang Terdaftar di Bursa Efek Indonesia 
Tahun 2012-2014). JOM Fekon. Vol.4 No.1

Ross, S. A. (1977). The Determination of Financial Structure: The Incentive Signaling Approach. Bell Journal of Economics and Management Science, Vol. 8 (1): 23-40.

Sartono, Agus. (2015). Manajemen Keuangan: Teori dan Aplikasi. Edisi Keempat. BPFE : Yogyakarta

Satryatama, Affandi. (2015). Pengaruh Earnings Power Dampaknya Terhadap Praktik Manajemen Laba. Skripsi Program Studi Fakultas Keguruan dan Ilmu Pendidikan Universitas Nusantara PGRI Kediri Savitri, Enni. (2014). Analisis Pengaruh Leverage dan Siklus Hidup Terhadap Manajemen Laba Pada Perusahaan Real Estate dan Property yang Terdaftar di Bursa Efek Indonesia. Jurnal Akuntansi. Vol.3 No.1, hlm. 72-89

Schipper, K. (1989). Commentary on Earnings Management. Accounting Horizon, 3 (4: 91 - 102)

Selviani, A., Heni. (2017). Pengaruh Profitabilitas, Leverage, dan Ukuran Perusahaan Terhadap Manajemen Laba (Studi Empiris pada Perusahaan Manufaktur yang Terdaftar di Bursa Efek Indonesia Tahun 2014-2016). Skripsi Program
Studi Akuntansi Fakultas Ekonomi Universitas Sanata Dharma

Simarmata, R., Hamdani. (2014). Pengaruh Ukuran Perusahaan dan Leverage Terhadap Manajemen Laba (Studi Kasus pada Perusahaan Sektor Pertanian yang Terdaftar di Bursa Efek Indonesia). Skripsi Program Studi Akuntansi Fakultas Ekonomi Universitas Komputer Indonesia

Sosiawan, S., Yuliana. (2012). Pengaruh Kompensasi, Leverage, Ukuran Perusahaan, Earnings Power Terhadap Manajemen Laba. JRAK. Vol.8 No.1

Sulistyanto, H., Sri. (2008). Manajemen Laba Teori dan Model Empiris. PT Gramedia Widiasarana Indonesia : Jakarta

Surya, S., Soetama, D., R., \& Ruliana, R. (2016). Pengaruh Earning Power Terhadap Earning Management. Akuntabilitas: Jurnal Ilmu Akuntansi. Vol.9 No.1

Suwito, Edy., Herawaty, Arleen. (2005). Analisis Pengaruh Karakteristik Perusahaan Terhadap Tindakan Perataan Laba Yang Dilakukan Oleh Perusahaan Yang Terdaftar Di Bursa Efek Indonesia. Simposium Nasional Akuntansi VIII Solo 15 - 16 September 2005

Suyoto, H., \& Dwimulyani, S. (2019). Pengaruh Leverage dan Perencanaan 
JAFTA - Vol 3 Nomor 1, Maret (2021)

Pajak Terhadap Manajemen Laba

Dengan Profitabilitas Sebagai

Variabel Moderasi. Prosiding

Seminar Nasional Pakar 2019

Taco, C., \& Ilat, V. (2016). Pengaruh

Earning Power, Komisaris

Independen, Dewan Direksi, Komite

Audit dan Ukuran Perusahaan

Terhadap Manajemen Laba pada

Perusahaan Manufaktur yang

Terdaftar di Bursa Efek Indonesia.

Jurnal EMBA. Vol.4 No.4, hlm. 873-

884

Widianingrum, R., \& Sunarto. (2018).

Deteksi Manajemen Laba: Leverage, Free Cash Flow, Profitabilitas dan Ukuran Perusahaan (Studi Kasus pada Perusahaan Manufaktur yang Terdaftar di BEI Periode 20132016). Prosiding SENDI_U

Wiyadi, Trisnawati, Rina., Sasongko, Noer, dan Fauzi, Ichwani. (2015). "The Effect of Information Asymmetry, Firm Size, Leverage, Profitability and Employee Stock Ownership on Earnings Management with Accrual Model". International Journal of Business, Economics and Law, 8(2), 21-30. 